\title{
Climate Change and Fishermen In and Around Uran. Dist Raigad.(Maharashtra)
}

\author{
Sandhya Kupekar and *Balasaheb Kulkarni \\ Mahatma Phule A.S.C.College, Panvel (Raigad) 410206. \\ * Institute of Science, Madam Cama Road, Mumbai.400 032.
}

\begin{abstract}
Fish which is an important diet of millions across the world is under severe threat caused by climate change. Changes in fish population and ecosystem from climate change are likely to have resulting impacts on fisheries sector and national economics. Climate change may also directly affect fishing operations and fishing communities independently of impacts on fish and ecosystem. Uran coast which forms the part of main land of Konkan lies along the Eastern of Bombay harbor opposite Colaba. Coastal ecosystem in and around Uran is very likely to be affected by climate change. However, illiterate fishermen community is not aware regarding causes of climate change and its terrible consequences. Therefore, a survey is being conducted, on what fishermen in Uran and around Uran think about climate change, climate change science, and schemes of State and central Government of India to fight out climate change effects. The aim of the survey was to identify whether fishermen, knows that climate change is real one and their attitude towards possible issues of climate change. Over 500 fishermen in and around Uran were surveyed during January to May 2010 for their views on climate change issues. It has been noticed that most of the fishermen were unaware about climate change and its consequences. However, they are worried about declining fisheries resources. Concerned over the depleting fish count, one of the fishermen expressed view that they used to get fresh Pomfret and prawns in the creek. But due to severe chemical emission from industries, a large number of fish have died. The emission is really bad during the monsoon, which is breeding period of the fish. Response of fishermen was divided into three groups like skeptics, acceptors and undecided. Among the problems faced by fishermen limiting fishing days, quality and quantity of harvested fish was voiced by fishermen and they are looking forward to Government to protect fish resources and help to improve their standard of life. The results of present survey also reveal importance of awareness program about climate change among the fishermen community.
\end{abstract}

Key Words: Uran, Fishermen, Fish, Climate, Ecosystem

\section{Introduction:}

Maharashtra with a coast line of $720 \mathrm{~km}$ ranks second among the maritime states of India in respect of marine fish landings. There are 153 landing centers situated in the five coastal districts namely, thane, Greater Bombay. Raigad, Ratnagiri and Sindhudurg. There state, which has a continental shelf of 89,096 square kilometer, offers rich potential for marine fisheries. The areas of potential fishing ground in $0-50 \mathrm{~m}$ depth and 50-200 m depth are 2.55 and 10.48 million hectares respectively. Millions of people around the world depend on fisheries and aquaculture Prasad et al,.1973., directly or indirectly, for their livelihoods Silas et al,.1976., Ziervogel \& Calder (2003). During the past three decades, the number of fishers and aquaculturists has grown faster than the world's population ,Alber,et al.,(2000), Bakun A. (1990), Bigg, et al.,(2003) and employment in the fisheries sector has grown faster than employment in traditional agriculture.In 2004, an estimated 41 million people worked (part time or full time) as fishers and fish farmers,. The great majority of fishers and fish farmers are in developing countries, principally in Asia .Life on earth is possible because the sun's energy warms the earth and its atmosphere. As this warmth radiates back into space, a portion is absorbed by a delicate balance of heat-trapping gases in the atmosphere, creating an insulating layer. The insulating layer, functioning much as a conventional greenhouse does, acts to elevate temperatures on earth. This "greenhouse effect" is a necessary natural global mechanism. Luam Kong, A. (2002). Without it the earth's climate would be hostile to human life. Human contributions to greenhouse gases (GHG) have led to an "enhanced greenhouse effect," Eide, \& Heen, (2002). often referred to as climate change or global warming. Today's atmospheric concentrations of carbon dioxide (CO2), the primary GHG, are 30 percent above the pre-industrial levels of 200 years ago. At present rates, they may double as early as 2050.The rapidly changing weather pattern blamed on global warming is hurting the fishing industry, depriving fishermen and their families not only of income but also their own places to live. Fishermen on the island would usually go out to sea from January to May. But the fishing season has become shorter as heavy rains and strong waves now begin as early as late March or early April, but their pockets are not the only ones hurting: However, the Government appears unprepared to support fishermen as well as farmers and other poor segments of the population whose livelihood are threatened by global warming. Uran coast which forms the part of main land of Konkan lies along the Eastern of Bombay harbor opposite 
Colaba. Coastal ecosystem in and around Uran is very likely to be affected by climate change. However, illiterate fishermen community is not aware regarding causes of climate change and its terrible consequences. Therefore, a survey is being conducted, on what fishermen in Uran and around Uran think about climate change, climate change science, and schemes of State and Central Government of India to fight out climate change effects.

\section{Study Area:}

\section{Materials And Methodes:}

Geographically, Uran with the population of 23,251 is located along the eastern shore of Mumbai harbour opposite to Coloba.Uran, which forms the part of the mainland of Konkan,. Entrance to the Harbour lies between prongs Reef marked by a lighthouse at the southern tip of Mumbai and Thal Reefs lying off the mainland to the southeast. The creek is approximately $8 \mathrm{~km}$ broad at the mouth and narrows down to a few meters at the head, near Thana Railway Bridge. The southern section of the port waterfront extends $7 \mathrm{~km}$ from Prongs Reef lighthouse through Coloba and Sasson Dock to the heart of the Mumbai City. Immediate to the north, covering a waterfront length of nearly $8 \mathrm{~km}$., are the naval installations and the main commercial port facilities consisting of docks and bunders. Two islands lie towards the northeast limit of the Port. The smaller and more westerly of these is Butcher Island, the site of a marine oil terminal. Elephanta Island, $2 \mathrm{~km}$ east of Butcher Island, is primarily of historical, archeological and tourist interest. To the north of Butcher Island in Trombay, the site of a nuclear power facility.

Uran and nearby coastal area of it is surrounded by industrial plants including Jawaharlal Nehru Port Trust (JNPT), L.P.G. plant of O.N.G.C., Grindwell Norton Ltd., M.S.E.B. Gas Turbine Power Station, Bharat Petroleum Corporation Ltd., Nhava-Sheva International Container Terminal (NSICT), Container Freight Stations (CFS) and many small scale industries of chemical production. Under such circumstances coastal area of Uran is slowly becoming a ground of chemical pollution Fish which is an important diet of millions across the world is under severe threat caused by climate change. Changes in fish population and ecosystem from climate change are likely to have resulting impacts on fisheries sector and national economics. Climate change may also directly affect fishing operations and fishing communities independently of impacts on fish and ecosystem. Therefore, a survey is being conducted, on what fishermen in Uran and around Uran think about climate change.

500 fishermen's families has been surveyed for this study by using following questioning.

\section{QUESTIONING:}

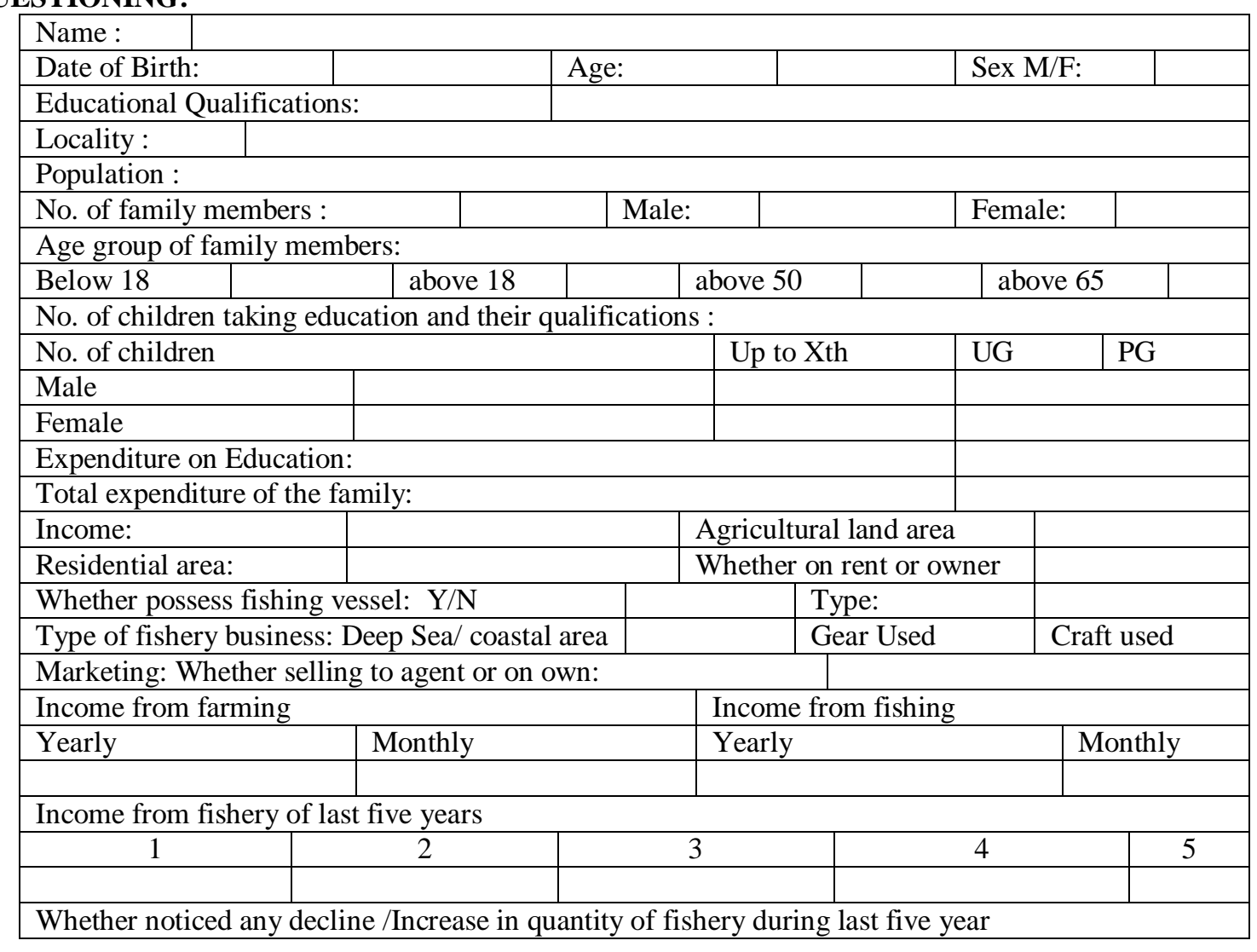




\begin{tabular}{|l|}
\hline \\
\hline Whether noticed any change in pattern of rain during last five year \\
\hline In your opinion effect of change of rain pattern on fishing \\
\hline Your future plan for effective fisheries \\
\hline What will you do if your income from fishery will not sufficient to fulfill your need? \\
\hline
\end{tabular}

\section{General Map of Study Areas:}

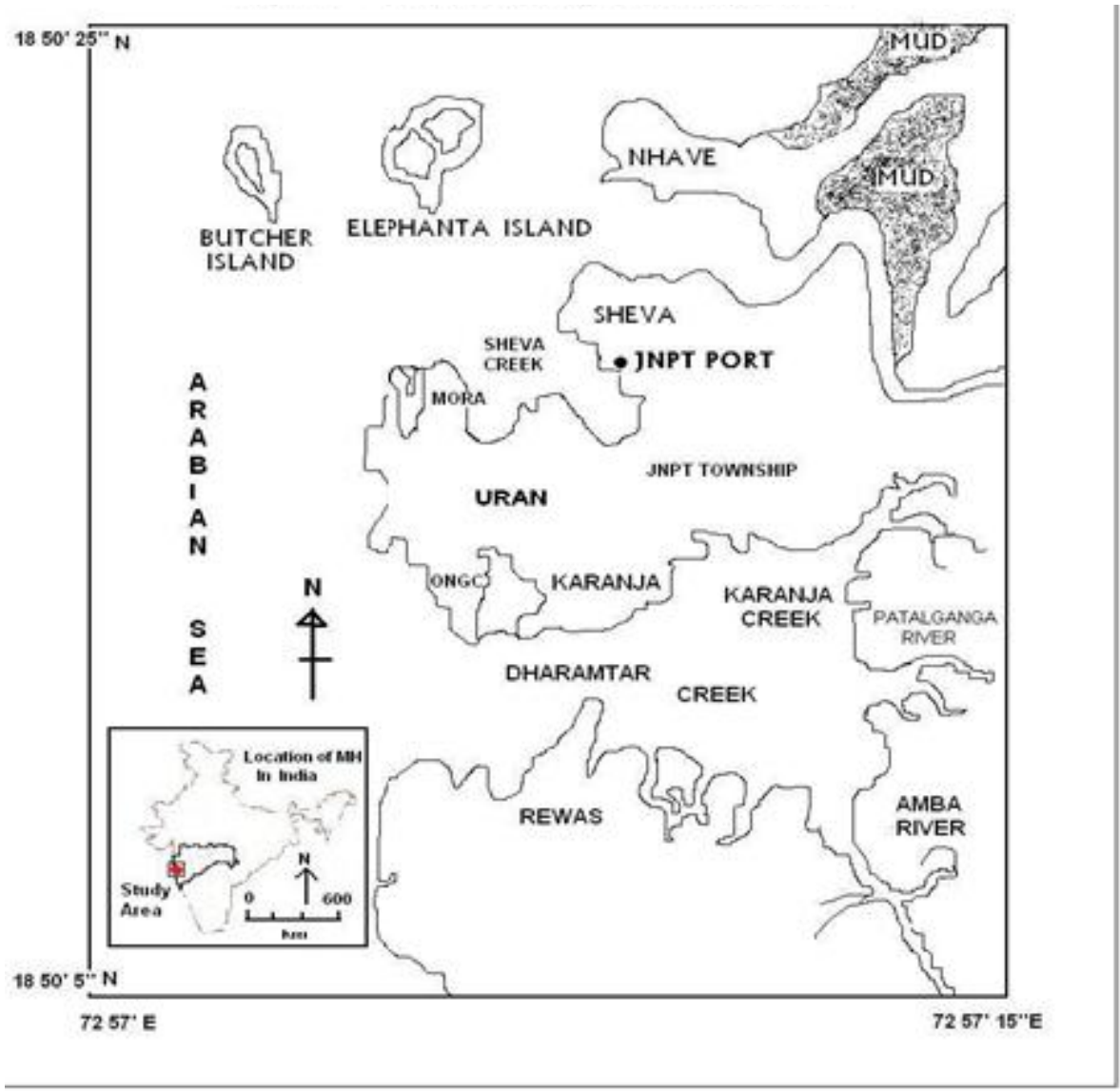

\section{Result And Discussion:}

500 fishermen's families has surveyed for this study. Out of these 500 families 800 male and 700 females are surveyed. 3 to 4 children found in these families where majority children are female. They are not well educated. Most of children are taking education up to $\mathrm{X}^{\text {th }}$ class. Very few are graduates as well as post graduates. Though they are having agricultural area where they can take production of rice. In this study 500 fishermen's families are surveyed and they are divided in three income groups. It has been noticed that most of the fishermen were unaware about climate change and its consequences Response of fishermen was divided into three groups like skeptics, acceptors and undecided. However, they are worried about declining fisheries resources the following table is showing the details of monthly and yearly income of these three groups. Fishermen grouped in three categories according to their monthly as well as annual income. First group income between Rs. 70,000 to 80,000, Second group income between 1,00,000 to 2,00,000 and Third group income between $2,00,00,000$ to $4,00,00,000$. 


\begin{tabular}{|c|c|c|c|c|c|c|}
\hline \multirow{3}{*}{ No. of Fishermen } & \multirow{2}{*}{\multicolumn{2}{|c|}{$\frac{\text { Ist Group }}{150}$}} & \multirow{2}{*}{\multicolumn{2}{|c|}{$\begin{array}{c}\text { IInd Group } \\
200\end{array}$}} & \multirow{2}{*}{\multicolumn{2}{|c|}{$\frac{\text { IIIrd Group }}{150}$}} \\
\hline & & & & & & \\
\hline & Monthly & Yearly & Monthly & Yearly & Monthly & Yearly \\
\hline Income & 6000 & 72000 & 8400 & 100800 & 325000 & 3900000 \\
\hline
\end{tabular}

Table1.2 Income from fishery of last five years (In Rs.)
\begin{tabular}{|l|c|c|c|c|c|}
\hline \multicolumn{1}{|c|}{ No. of fishermen } & $\mathbf{1}$ & $\mathbf{2}$ & $\mathbf{3}$ & $\mathbf{4}$ & $\mathbf{5}$ \\
\hline Ist Group 150 & 60000 & 45000 & 49000 & 40000 & 35000 \\
\hline IInd Group 200 & 300000 & 250000 & 230000 & 220000 & 210000 \\
\hline IIIrd Group 150 & 5000000 & 4000000 & 4500000 & 3400000 & 3200000 \\
\hline
\end{tabular}

The five-year evaluation found that about one third of open sea fisheries have already collapsed, a trend exacerbated by the changes produced by broader losses in marine biodiversity. The fisherman pointed to fishing, pollution, climate change, increasing acidity of the ocean and the destruction of marine habitats as some of the key factors for the decline. The over-exploitation and mismanagement of fisheries has already led to some spectacular fisheries collapses. The effects of climate change on fisheries will impact a sector that is already characterized by full utilization of resources, large overcapacity and conflicts among fishers, and others, vying for alternative uses of marine ecosystems. Thus, climate change adds a further argument for developing effective and flexible fisheries fishermen here have been affected by the large-scale depletion of fish," said the fisherman Anupama Nakhava. The impact of climate change will adversely affect people living off the coast. Many of fishermen will lose their livelihood said Hareshwar Nakhwa. Dayanand said over the last decade, around 25\% of Navi Mumbai's mangrove cover has been destroyed. There are 12,485 boats, comprising mechanized boats, plank built boats and dug-out canoes. Among 4557 mechanized boats, bag netters constitute $40 \%$ followed by trawl netters (35\%), gillnetters (20\%) and the rest long liners. Out of 2366 plank-built boats $49 \%$ are gill netters $29 \%$ are bag netters, $9 \%$ are Rampanis and the rest are long liners. Out of $536043 \%$ dugout canoes are gill netters, $29 \%$ are bag netters and the rest are the long liners, Rampanis and others. Among the gears employed, gill nets are 244,390 in number, followed by bag net (20523), trawl nets (4152) and Rampani (99). There are 42047 nets such as cast nets which are in the categories other than given above. Fisherman Ashok Koli said that at current rates, fish stocks risked declining to an extent that would render commercial fishing impossible and recovery unlikely. Concerned over the depleting fish count Vasant Koli a fisherman said, "We used to get fresh pomfret and prawns in the creek. But due to severe chemical emission from industries, a large number of fish have died. The emission is really bad during the monsoon when the fish breed." Women are more dependent for their livelihood on natural resources that are threatened by climate change. For instance, climate change causes a rise in the sea level, affecting the fishing community (both men and women) not only in terms of fish-catch but also with regard to water scarcity, as sea water gets into fresh water. We see small dead fish floating in the seas because of effluents being released into the sea, the fish have gone 40 kilometres away said 44 year-old fisherman. Bhalchandra Koli said that around 30-35 indigenous fish species have disappeared, including varieties of shark, big snapper and the well-known delicacy, 'Bombay duck'. Fishermen's unions speak of overall government neglect of traditional fishermen, with help being extended only to the mechanized trawling sector. The women mostly wives of fishermen are fish-vendors who are also impacted by dwindling fish catches, lesser incomes, lack of proper storage and poor transportation. Vinod Nakhwa confirms that fishermen know that the decline in rainfall has affected fish-breeding.

The best help for the community is to restore the mangroves that have been devastated by human activity all over India's coastlines."Mangroves provide a multiplicity of adaptation and mitigation options. Fishing is almost throughout the year except during the monsoon period. Several types of boats mechanized and non-mechanized are using different gear land their catches. Bombay duck, non penaeid prawns, penaeid prawns, pomfrets, elasmobranhs, perches and ribbon fishes are some of the commercially important groups which form the bulk of landings. Purchasing fuel as they need to use the boats for an average of $60 \mathrm{~km}$ each time for a catch. This has caused the input cost on fishing to go high, which in turn affects the price of fish. The change has also caused 1 in every 3 fisher folk in the region to seasonally migrate to nearby cities. Raigad district have advised people not to consume fish for some time, as they might be contaminated due to the oil spill near the Mumbai harbor which causes gastroenteritis, renal failure. Experts say that the effects of toxins in fish may not be immediately visible, but may manifest over a period of time.

Climate change is already modifying the distribution of both marine and freshwater species. Warmerwater species are being pushed towards the poles and experiencing changes in habitat size and productivity. Climate change is affecting the seasonality of biological processes, altering marine and freshwater food webs, with unpredictable consequences for fish production. The government response is promising on paper, but in reality, what is it doing for the small fishermen, for the urban poor? The study said, urgent efforts are needed to 
help fishing communities, strengthen their resilience to climate change, especially those who are most vulnerable. The primary focus of this study is to generate an understanding of climate change impacts on fisheries and fishing communities, "A lot can be done only if the Government understands that the sea is our life and coast is our right. The Government should introduce more low cost net making mechanisms for the fisher folk.

Among the problems faced by fishermen limiting fishing days, quality and quantity of harvested fish was voiced by fishermen and they are looking forward to Government to protect fish resources and help to improve their standard of life. The results of present survey also reveal importance of awareness programme about climate change among the fishermen community.

\section{References :}

[1]. Abler, D., J. Shortle 1, et al. (2000): "Characterizing regional economic impacts andresponses to climate change." Global and Planetary Change 25: 67-81.

[2]. adjoining seas. Indian. J. Anim. Sci., 40(1) : 73-98.

[3]. Bakun A. (1990): Global Climate Change and Intensification of Coastal OceanUpwelling. Science 247: 198-201.

[4]. Bigg, G.R., Jickells, T.D., Liss, P.S. and Osborn, T.J. (2003): The role of the oceansin climate. Interational Journal of Climatology 23, 1127-1159.

[5]. Brody M. \& Hlohowskyj I. (1998): Fisheries. In: Handbook on Methods of Climate Change Impact Assessment and Adaptation Strategies (eds. J. F. Feenstra, I.

[6]. Chong, K., (1993): Socio-economic issues in coastal fisheries management, labourabsorption in fisheries: inevitable trends and prospects in employment creation, In: Proceedings of the FAO Symposium on Fisheries Management in SE Asia. FAO, Rome, pp 49-69.

[7]. Eide, A. \& Heen, K. (2002): Economic impacts of global warming: A study of the fishing industry in North Norway. Fisheries Research, 56, 261-274.

[8]. Healey, M. C. (1990): "Implications of climate change for fisheries management policy." Transactions of the American Fisheries Society 119(2): 366-373.),

[9]. Luam Kong, A. (2002): Impact of climate changes on Caribbean fisheries resources: research needs. Caribbean food systems: Developing a research agenda, 19- 20 September 2002, St Augustine, Trinidad, Global Environmental Change and Food Systems (GECAFS).

[10]. MAHARASHTRA. (1982): Census of fishermen boats and nets. Department of Fisheries. Govt, of Maharashtra, Bombay.

[11]. McCauley, R. and T. Beitinger (1992): "Predicted effects of climate warming on the commercial culture of the channel catfish, Ictalurus punctatus." GeoJournal 28(1): 61-66.

[12]. Nair, R. V. (1970): Is there over fishing of our inshore fishery resources?Seafood Export Journal, vol. VII No. 4

[13]. Panikkar, N. K. (1966): Fishery resources of the Indian Ocean. Curr. Sci.35(18): 455.PRASAD, R. R., S.K BANERJI AND P.V. RAMACHANDRAN NAIR. 1970. Quantitativeassessment of the potential fishery resources of the Indian Ocean and

[14]. Prasad, r. R. And p. V. Ramachandran nair (1973): India and the IndianOcean fisheries. J. mar. biol. Ass. India. 15(1) : 1-19.J. mar. bid, Ass. India. 8(1) : 205-211.

[15]. Rao, k. Virabhadra, k. Dorairaj. P. V. Kagwade and d. M. Punwani (1968): Results of the exploratory fishing operations of the Government of India vessels at Bombay base for the period 1961-67. Symposium on demersal fishes at the 13 th session of the IPFC, Brisbane, AustraliaOctober 1968.

[16]. Sagua V. O. (1993): The effects of climate change on the fisheries of the Sahel. FAO, Rome.

[17]. Silas, e. G, s. K. Dharmaram and k. Rengaramn. (1976): Exploited marine fishery resources of India-a synoptic survey with comments on potential resources. Bull. Cent. Mar. Fish. Res. Inst., 27 : 1-25..

[18]. Thakraborthy, s. K., v. D. Deshmukh, kuber vidyasagar and s. Ramamurthy. (1983): Bycatch of shrimp trawlers in greater Bombay. Mar,Fish. Infor. erv. T\& E Ser., 54:7-15.

[19]. Ziervogel, G. \& Calder, R. (2003): Climate variability and rural livelihoods: assessing the impact of seasonal climate forecasts in Lesotho. Area, 35, 403-417.

\section{Acknowledgement:}

Authors are thankful to Prin. Dr. Ganesh Thakur, Mahatma Phule Arts, Science \& Commerce College, Panvel for providing facilities for carrying out the present investigation.

Authors are sincerely thankful to Mr. S. M. Udawant, Head, Department of Zoology, Prof. R.K. Patil and all respected colleagues of Mahatma Phule Arts, Science and Commerce College, Panvel for their support during the work. 
Climate Change And Fishermen In And Around Uran. Dist Raigad.(Maharashtra)
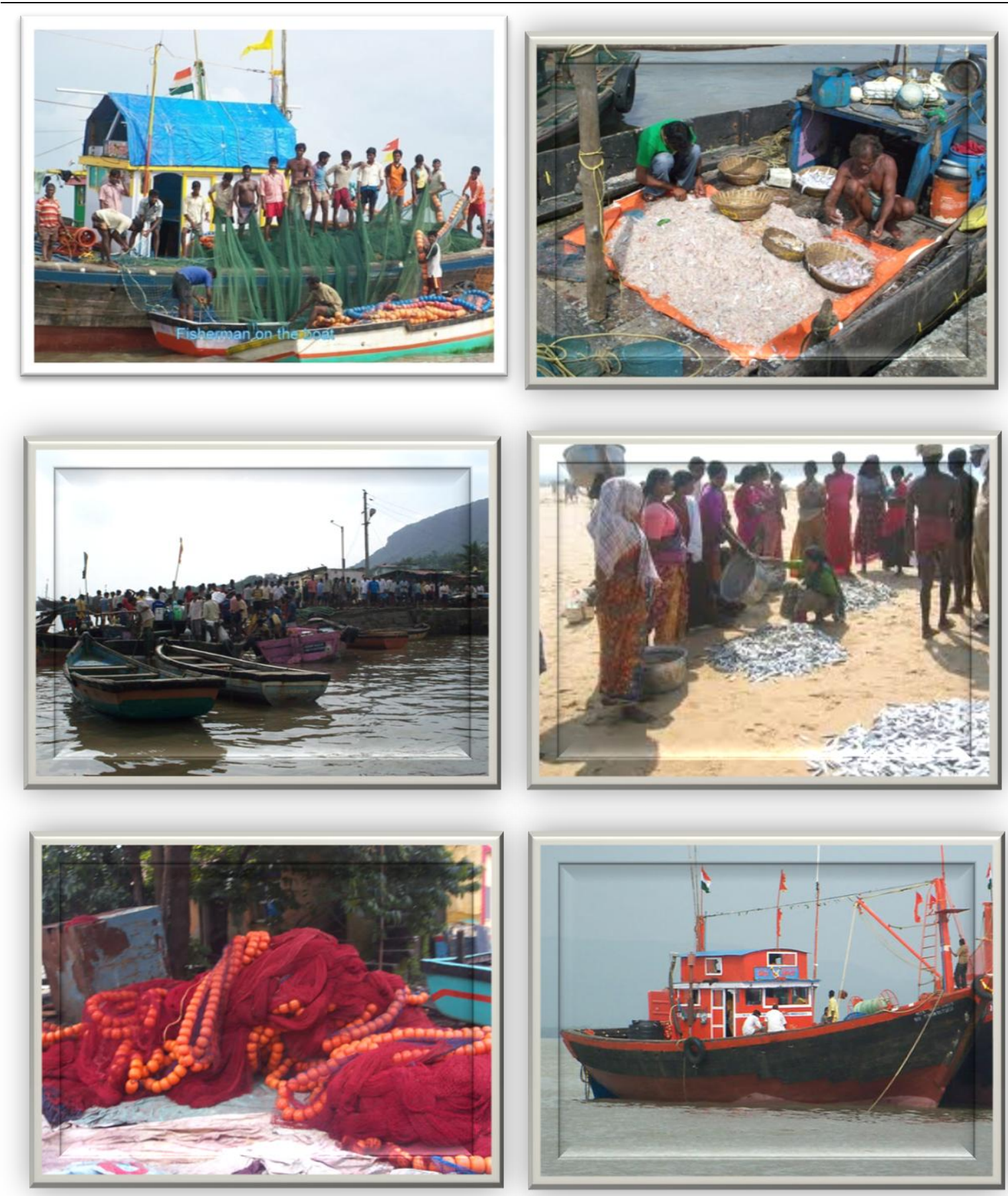